\title{
FAKTOR-FAKTOR YANG MEMPENGARUHI BURNOUT PADA WANITA BEKERJA DI KABUPATEN BANYUMAS
}

\author{
Keksi Girindra Swasti ${ }^{1}$, Wahyu Ekowati2 ${ }^{2}$ Eni Rahmawati ${ }^{3}$ \\ 1,2,3Staf pengajar Jurusan Keperawatan, Fakultas IImu-ilmu Kesehatan, Universitas \\ Jenderal Soedirman \\ email: keksi_girindra@yahoo.com
}

\begin{abstract}
The globalization era has given many changes in some aspects of life such as women participation in work field. The effects of doing their role, women oftentimes feel weary not only physical but also mental and emotional therefore it can influence their work performance and personal life. This condition is called by "burnout". Burnout is influenced by individual, environment and cultural factor. Based on that problem, the researcher was interested to find out some factors that influence burnout for working women in Banyumas Regency. This research was quantitative by corelative analysis design and the sample was chosen by simple random sampling. The relationship between characteristic of respondent demography and burnout were analyzed by Chi-Square and Sommers $d$ test. The result of analysis are $55 \%$ respond are mild burnout and $42,5 \%$ are moderate burnout. Level of education, kind of work, amount of income and work duration were some factors that influence burnout for working women in Banyumas Regency. Based on that fact, it is needed some efforts to prevent sustainable burnout by developing comfort environment's work and educate support system.
\end{abstract}

Keywords: burnout, working, women

\section{ABSTRAK}

Era globalisasi telah memberikan banyak perubahan dalam berbagai aspek kehidupan, termasuk partisipasi wanita dalam lapangan pekerjaan. Dalam menjalankan perannya, seringkali wanita merasakan kelelahan yang berlebihan, tidak hanya fisik namun juga mental dan emosional yang kemudian berimbas pada performa kerja dan kehidupan personalnya. Kondisi ini dikenal dengan istilah burnout. Burnout dipengaruhi oleh faktor individu, lingkungan, dan budaya. Penelitian ini bertujuan untuk mengetahui faktor-faktor yang mempengaruhi burnout pada wanita bekerja di Kabupaten Banyumas. Penelitian ini merupakan penelitian kuantitatif dengan desain analisis korelatif. Sampel dipilih secara simple ramdom sampling. Analisis hubungan karakteristik demografi responden dengan burnout dilakukan dengan Uji Chi Square dan Sommers d. Hasil analisis diketahui bahwa $55 \%$ responden mengalami burnout ringan dan 42,5\% lainnya mengalami burnout sedang. Burnout pada wanita bekerja di Kabupaten Banyumas dipengaruhi oleh faktor tingkat pendidikan, jenis pekerjaan, penghasilan, dan jam bekerja. Perlu diciptakan lingkungan kerja yang nyaman dengan support system yang adekuat, serta penghargaan yang sesuai untuk menurunkan burnout.

Kata kunci: burnout, bekerja, wanita. 


\section{PENDAHULUAN}

$$
\text { Era globalisasi telah }
$$

memberikan banyak perubahan dalam berbagai aspek kehidupan, termasuk partisipasi wanita dalam lapangan pekerjaan. Data badan Pusat Statistik tahun 2017 menunjukkan tingkat partisipasi angkatan kerja wanita meningkat 2,33 persen poin, dari 52,71 persen pada tahun 2016 menjadi 55,04 persen. Bahkan tren yang berkembang, perusahaan lebih berminat untuk merekrut tenaga kerja wanita daripada laki-laki. Tidak sedikit juga wanita yang mampu menunjukkan potensinya dalam menjalankan peran diberbagai bidang keahliannya, sehingga wanita mendapatkan peluang karir yang setara dengan laki-laki. Peran dan tanggung jawab dalam pekerjaan seringkali memberikan stressor bagi pekerja. Stressor yang berlebihan dalam waktu yang berkepanjangan dapat menimbulkan stres.

Hasil penelitian di Jerman menunjukkan bahwa $8 \%$ pekerja mengalami stres kerja yang dirasakan selama 30 hari. Stres kerja tersebut memberikan dampak tidak hanya pada tempat kerja tetapi juga kehidupan pribadi pekerja, seperti memburuknya kondisi dalam keluarga dan hubungan pertemanan (Nink, 2015). Keluhan yang dirasakan oleh pekerja saat mengalami stres berkepanjangan diantaranya lelah saat bangun tidur di pagi hari, perasaan bersalah dalam pekerjaan, dan penurunan performa kerja. Kondisi tersebut mengindikasikan terjadinya burnout. Burnout adalah sindrom yang berhubungan dengan pekerjaan yang ditandai dengan tingkat kelelahan yang berlebihan, sinism, dan penurunan efikasi profesional. Kelelahan yang dirasakan tidak hanya fisik, tetapi juga mental dan emosional (Schaufelly, 2009).

Menurut Sullivan dalam Spector (2008) burnout dapat disebabkan oleh faktor individu, lingkungan, dan budaya. Termasuk dalam faktor lingkungan adalah konflik peran. Pekerjaan yang tidak sesuai dengan bidang keahlian juga dapat memicu terjadinya burnout. Begitu pula dengan peran ganda, seorang wanita yang berperan sebagai pekerja dan ibu rumah tangga akan lebih berpotensi mengalami burnout. Faktor lainnya adalah beban kerja yang berlebihan, meliputi lamanya jam kerja, banyaknya tanggungjawab yang harus diterima, dan banyaknya tugas yang harus diselesaikan. Keterlibatan terhadap pekerjaan, tingkat fleksibilitas waktu kerja, dan dukungan sosial juga mempengaruhi terjadinya burnout (Alarcon, 2011).

Selain faktor lingkungan, burnout juga dipengaruhi oleh faktor individu seperti jenis kelamin, usia, etnis, status perkawinan, tipe kepribadian, konsep diri, dan kemampuan mengendalikan emosi (Sullivan, 1989). Burnout berpotensi dialami oleh pekerja laki-laki maupun wanita, terlebih dengan adanya kesetaraan gender. Meskipun beberapa penelitian menunjukkan bahwa seseorang yang belum menikah berisiko mengalami burnout lebih tinggi, namun pernikahan memberikan tambahan peran sosial. Seorang wanita yang sudah menikah dan bekerja seringkali mengalami dilema dalam bekerja. Jenis pekerjaan juga turut berperan memicu terjadinya burnout. Hasil penelitian Hadi (2009) menunjukkan bahwa profesi yang paling tinggi mengalami burnout adalah profesi kesehatan, selain profesi pelayanan publik lainnya seperti guru atau tenaga pendidik, dimana profesi tersebut banyak digeluti oleh wanita. 
Pada beberapa bidang pekerjaan, terkadang pekerja masih harus membawa pekerjaan kantor ke rumah, padahal anggota keluargapun menuntut perhatian dari pasangan atau orang tuanya. Begitupun sebaliknya, saat ada masalah dalam keluarga seperti anak sakit, sedangkan kedua orang tua bekerja, maka ibulah yang akhirnya memutuskan untuk tidak bekerja. Bahkan pada sebagian pekerja wanita harus menggunakan sebagian waktu kerjanya untuk mengerjakan urusan keluarga seperti mengurus sekolah, mengantar, atau menjemput anak. Padahal setiap pekerja pasti terikat dengan aturan dan norma sosial di tempat kerja. Kondisi ini akan berimbas pada performa kerja dan kehidupan personal pekerja.

Hasil wawancara dengan 5 wanita bekerja yang berdomisili di wilayah Kabupaten Banyumas, 2 dari 3 pekerja wanita yang sudah menikah mengeluhkan bahwa tidak bisa berperan optimal baik sebagai ibu maupun saat bekerja di kantor. Dua orang mengatakan bahwa performa kerjanya tidak maksimal karena pekerjaan yang terlalu banyak. Empat pekerja mengeluhkan badan terasa mudah lelah, rasa penat yang teramat sangat, dan merasa tidak segar saat bangun tidur. Melihat kondisi tersebut, penulis tertarik untuk mengetahui faktor-faktor yang mempengaruhi burnout pada wanita bekerja di Kabupaten Banyumas.

\section{METODE PENELITIAN}

Penelitian ini merupakan penelitian kuantitatif dengan desain analisis korelatif. Penelitian dilakukan pada bulan Maret - Agustus 2017 di wilayah Kabupaten Banyumas. Sampel dipilih secara acidental sampling sejumlah 200 wanita bekerja di wilayah Kabupaten Banyumas. Pengumpulan data menggunakan instrumen Maslach Burnout Inventory (MBI) yang sudah dilakukan uji validitas dan reliabilitas oleh peneliti sebelumnya. Analisis hubungan karakteristik demografi responden dengan burnout dilakukan dengan Uji Chi Square dan Sommers d.

\section{HASIL}

Berikut adalah hasil penelitian yang disajikan dalam bentuk tabel.

Tabel 1. Gambaran burnout pada wanita bekerja di wilayah Kabupaten Banyumas

\begin{tabular}{|c|c|}
\hline Kategori burnout & Frekuensi $\quad$ Persentase (\%) \\
\hline Tidak burnout & 0,5 \\
\hline Burnout ringan & 110 \\
\hline Burnout sedang & 42,5 \\
\hline Burnout berat & 4 \\
\hline Jumlah & 200 \\
\hline \multicolumn{2}{|c|}{ Sumber data primer Mei - Juli 2017} \\
\hline \multicolumn{2}{|c|}{$\begin{array}{l}\text { Berdasarkan tabel } 1 \text {. diketahui } \\
\text { mayoritas pekerja wanita di } \\
\text { ten Banyumas mengalami } \\
\text { ringan sebanyak } 55 \% \text {, disusul } \\
\text { burnout sedang } 42,5 \% \text {. Terdapat } \\
\text { yang mengalami burnout berat } \\
\text { ak } 4 \text { orang. }\end{array}$} \\
\hline
\end{tabular}


Tabel 2. Hasil analisis faktor-faktor yang mempengaruhi burnout pada wanita bekerja di wilayah Kabupaten Banyumas $(\mathrm{N}=200)$

\begin{tabular}{|c|c|c|c|c|c|}
\hline \multirow{2}{*}{$\begin{array}{l}\text { Variabel faktor-faktor yang } \\
\text { mempengaruhi burnout }\end{array}$} & \multicolumn{4}{|c|}{ Burnout } & \multirow[t]{2}{*}{$P V$} \\
\hline & Tidak burnout & Ringan & Sedang & Berat & \\
\hline \multicolumn{6}{|l|}{ Usia } \\
\hline 1. $20-40$ tahun & 1 & 88 & 65 & 3 & 0,631 \\
\hline 2. $40-60$ tahun & 0 & 22 & 19 & 1 & \\
\hline 3. Lebih 60 tahun & 0 & 0 & 1 & 0 & \\
\hline \multicolumn{6}{|l|}{ Status pernikahan } \\
\hline 1. Belum menikah & 0 & 24 & 16 & 2 & 0,844 \\
\hline 2. Menikah & 1 & 83 & 67 & 2 & \\
\hline 3. Janda & 0 & 3 & 2 & 0 & \\
\hline \multicolumn{6}{|l|}{ Jumlah anak } \\
\hline 1. belum memiliki anak & 0 & 32 & 23 & 2 & 0,964 \\
\hline 2. 1 orang & 0 & 20 & 23 & 1 & \\
\hline 3. 2 orang & 1 & 40 & 28 & 1 & \\
\hline 4. 3 orang & 0 & 16 & 6 & 0 & \\
\hline 5. Lebih dari 3 & 0 & 2 & 5 & 0 & \\
\hline \multicolumn{6}{|l|}{ Pendidikan } \\
\hline 1. D3 & 0 & 37 & 19 & 0 & 0,000 \\
\hline 2. $\mathrm{s1}$ & 1 & 69 & 29 & 0 & \\
\hline 3. $S 2$ & 0 & 4 & 34 & 3 & \\
\hline 4. $S 3$ & 0 & 0 & 3 & 1 & \\
\hline \multicolumn{6}{|l|}{ Pekerjaan } \\
\hline 1. Guru & 1 & 46 & 14 & 0 & 0,000 \\
\hline 2. Dosen & 0 & 4 & 36 & 4 & \\
\hline 3. Perawat & 0 & 37 & 20 & 0 & \\
\hline 4. Karyawan/staf & 0 & 23 & 15 & 0 & \\
\hline \multicolumn{6}{|l|}{ Jabatan struktural } \\
\hline 1. $\mathrm{Ya}$ & 0 & 17 & 15 & 1 & 0,879 \\
\hline 2. Tidak & 1 & 93 & 70 & 3 & \\
\hline \multicolumn{6}{|l|}{ Penghasilan } \\
\hline 1. Kurang & 0 & 66 & 28 & 1 & 0,000 \\
\hline 2.500 .000 & 1 & 29 & 22 & 1 & \\
\hline 2. Rp. $2.500 .000-$ Rp. & & & & & \\
\hline 5.000 .000 & 0 & 7 & 33 & 2 & \\
\hline 3. Rp. $5.000 .001-R p$. & & & & & \\
\hline 7.500 .000 & 0 & 8 & 2 & 0 & \\
\hline 4. Lebih Rp. 7.500 .000 & & & & & \\
\hline \multicolumn{6}{|l|}{$\begin{array}{lll}\text { Jam } & \text { kerja } & \text { dalam }\end{array}$} \\
\hline seminggu & 1 & 31 & 20 & 0 & 0,012 \\
\hline 1. Kurang 40 jam & 0 & 8 & 34 & 3 & \\
\hline 2. $40 \mathrm{jam}$ & 0 & 71 & 31 & 1 & \\
\hline 3. Lebih 40 jam & & & & & \\
\hline
\end{tabular}

Sumber data primer Mei - Juli 2017

Tabel 2. menunjukkan bahwa terdapat empat faktor yang mempengaruhi burnout pada wanita bekerja di wilayah Kabupaten Banyumas yaitu tingkat pendidikan, jenis pekerjaan/profesi, penghasilan dengan nilai $p 0,000$, dan jam kerja dengan nilai p 0,012. Sedangkan usia, status pernikahan, jumlah anak, dan jabatan struktural tidak mempengaruhi terjadinya burnout karena memiliki nilai $p>0,05$. 


\section{PEMBAHASAN}

Menurut Maslach dan Leiter (2008), burnout adalah respon paparan stres kerja yang berkepanjangan yang memberikan efek negatif pada individu, organisasi, maupun pengguna pelayanan. Sedangkan menurut Pines dan Aronso dalam Nursalam (2015) burnout merupakan kelelahan secara fisik, emosional, dan mental yang disebabkan keterlibatan jangka panjang dalam situasi yang penuh dengan tuntutan emosional. Pekerja yang mengalami burnout akan menunjukkan gejala kelelahan kronis, sikap sinis dan negatif terhadap pekerjaan yang berdampak pada penurunan performa kerja dan kesehatan. Lebih lanjut, pekerja yang mengalami burnout pada tingkat tinggi yang berkelanjutan akan mengalami masalah fisik maupun psikologis (Bakker, Demerouti, \& SanzVergel, 2014). Menurut Peterson et al. (2008) masalah yang dialami seperti ansietas, depresi, gangguan tidur, kerusakan memori, dan nyeri leher. Masalah lainnya adalah sakit kepala dan peningkatan risiko infeksi (Mohren et al., 2009).

Pada penelitian ini respondennya adalah pekerja wanita yang berprofesi sebagai guru, dosen, perawat, dan karyawan. Hasil analisis univariat menunjukkan mayoritas pekerja wanita di Kabupaten Banyumas mengalami burnout ringan sebanyak $55 \%$, tidak terpaut jauh dengan burnout sedang sejumlah $42,5 \%$. Hasil ini sesuai dengan penelitian sebelumnya bahwa burnout banyak dialami oleh profesi tenaga kesehatan (Putnik \& Houkes, 2011), guru (Hakanen, Bakker, \& Shaufelli, 2006). Burnout yang dialami oleh profesi pelayanan publik berkaitan dengan adanya interaksi yang dinamis. Menurut Freudenberger (1974) dan
Maslach (1976) dalam Schaufeli, Leiter, dan Maslach (2008) bahwa burnout terjadi pada kondisi hubungan sosial yang mengalami perubahan dengan cepat.

Selain jenis pekerjaan, burnout pada pekerja wanita di Kabupaten Banyumas juga pengaruhi oleh tingkat pendidikan. Hasil ini sejalan dengan penelitian Maslach dalam Cooper et al. (2003) dan Sahin (2012). Hasil penelitian menunjukkan semakin tinggi tingkat pendidikan semakin tinggi tingkat burnout yang dialami. Dalam pekerjaan, tingkat pendidikan berbanding lurus dengan peran dan tanggung jawab. Pekerjaan yang ditekuni responden, merupakan profesi yang memiliki jenjang karir yang dikategorikan berdasarkan tingkat pendidikan. Jenjang karir ini berpengaruh terhadap peran pekerja. Sebagai contoh, seorang perawat lulusan D3 maka ia akan berperan sebagai perawat klinis. Tetapi ketika ia melanjutkan pendidikan hingga S1 maka ia akan mendapat peran tidak hanya sebagai perawat klinis, tetapi juga perawat pendidik dan perawat manajerial. Tanggung jawab pun meningkat saat ia melanjutkan pendidikan hingga jenjang S2, dimana ia pun harus berperan sebagai perawat peneliti (Keliat \& Akemat, 2010). Hal yang sama terjadi dalam area pendidikan. Kondisi ini menunjukkan adanya peningkatan beban kerja pada pekerja seiring dengan peningkatan tingkat pendidikan. Beban kerja yang berlebih memicu terjadinya burnout pada pekerja, sebagaimana ditunjukkan oleh penelitian Akhsani (2016). Pada awalnya pekerja berupaya mengantisipasi terjadinya burnout. Upaya antisipasi ini disebut sebagai work engagement. Work engagement memang tidak menyebabkan terjadinya burnout, namun 
mempengaruhi kepuasan kerja dan gejala depresi (Schufeli, 2006).

Faktor lain yang mempengaruhi burnout adalah penghasilan. Penghasilan merupakan bentuk penghargaan yang diterima pekerja terhadap kerja yang sudah dilakukan. Hasil ini didukung oleh penelitian Sahin (2012). Hasil penelitian menunjukkan adanya perbedaan penghasilan dari reponden penelitian. Menurut asumsi peneliti, perbedaan penghasilan ini berkaitan dengan status kepegawaian responden dan juga instansi tempat responden bekerja. Responden penelitian ini diambil dari instansi negeri dan swasta, dengan status sebagai pegawai pemerintah tetap maupun belum tetap. Status ini menentukan besaran penghasilan yang terima. Pada area pekerjaan responden, tidak ada pengklasifikasian tanggung jawab berdasarkan status pekerja. Pada kenyataannya, meskipun pekerja memiliki tanggung jawab yang sama namun hasil yang diterima dapat berbeda. Pekerja merasa puas ketika hasil kerjanya mendapatkan penghargaan yang setimpal. Kepuasan tersebut akan memotivasi pekerja untuk bekerja lebih giat dan bersemangat sehingga dihasilkan performa kerja yang positif. Akan tetapi, saat reward yang diterima tidak sesuai dengan upaya profesional yang dilakukan maka kondisi tersebut dapat mempercepat terjadinya burnout (Schufeli, 2006).

$$
\text { Hasil penelitian juga }
$$

menunjukkan ada hubungan antara jam kerja dengan burnout. Jam kerja merupakan waktu yang digunakan oleh pekerja untuk melakukan aktivitas kerja. Semakin lama jam kerja maka semakin tinggi risiko pekerja mengalami burnout, karena dengan bertambahnya jam kerja maka akan semakin banyak aktivitas yang dilakukan. Aktivitas dilakukan dengan menggunakan energi, baik aktivitas fisik maupun non fisik. Energi yang dikeluarkan dalam jumlah yang besar tanpa diimbangi oleh istirahat yang cukup menyebabkan pekerja mengalami kelelahan. Responden penelitian ini memiliki aktivitas kerja yang bervariasi dengan jam kerja yang juga bervariasi. Sebagian responden bekerja dengan aktivitas fisik yang cukup berat, seperti perawat. Sebagian lainnya bekerja dengan menggunakan kemampuan kognitif dengan aktivitas fisik yang lebih rendah. Meskipun demikian kedua kegiatan tersebut sama-sama memberikan dampak kelelahan bagi pekerja. Kelelahan tersebut dapat berupa kelelahan fisik (exhaution) maupun kelelahan emosional (cynicism) (Nelson, 2014).

Selain keempat faktor tersebut, pada penelitian juga teridentifikasi empat faktor lain, namun tidak mempengaruhi terjadinya burnout pada wanita bekerja di Kabupaten Banyumas. Pertama, faktor usia. Tidak berpengaruhnya usia terhadap burnout pada penelitian ini diasumsikan oleh peneliti karena sebaran usia responden yang kurang merata, dimana responden didominasi oleh kelompok dewasa muda. Menurut Maslach orang usia muda lebih berisiko mengalami burnout daripada yang berusia lebih tua. Para pekerja muda biasanya memiliki idealisme lebih tingi sehingga terkadang harapannya kurang realistis. Seiring bertambahnya usia, individu akan lebih stabil dan lebih matang, sehingga harapannya akan lebih realistis (Suharti \& Daulima, 2013). Selain itu, usia muda juga berkaitan dengan kemampuan menyelesaikan masalah. Pekerja yang berusia muda dianggap belum cukup pengalaman dan masih berada pada tahap adaptasi, 
sehingga lebih mudah mengalami konflik dan tertekan dengan pekerjaan. Selain karena sebaran usia yang tidak merata, hasil ini juga dipengaruhi oleh karakter pekerjaan. Pada penelitian ini tanggung jawab yang diterima responden tidak semata ditentukan oleh usia, tetapi kompetensi yang dimiliki. Responden bekerja sesuai kompetensi yang dimilikinya. Menurut Decy dan Ryan (2000), seseorang yang mengalami burnout disebabkan oleh kegagalan dalam mencapai kepuasan dalam kebutuhan psikologis dasar. Salah satu kebutuhan psikologis tersebut adalah kompetensi. Kompetensi ini dimiliki setiap orang tanpa ada batasan usia.

Kedua, faktor status perkawinan. Hasil penelitian menunjukkan responden yang belum menikah maupun sudah menikah sama-sama berpotensi mengalami burnout. Hasil ini diperkuat oleh penelitian Suharti dan Daulima (2013). Namun hasil ini bertentangan dengan penelitian Jackson dalam Cooper et al. (2003) dan Wills dalam Odgen (2004) bahwa individu yang berstatus single lebih berisiko mengalami burnout. Burnout yang dialami oleh pekerja yang masih single berkaitan dengan tidak adanya dukungan sosial dari pasangan. Tidak berpengaruhnya status perkawinan pada penelitian ini berkaitan dengan tipe keluarga di Indonesia. Karakteristik penduduk Indonesia memiliki tipe nuclear family, dimana seorang anak yang belum menikah akan tetap tinggal bersama keluarga meskipun sudah berusia dewasa. Oleh karena itu, meskipun mereka berstatus single namun mereka masih cukup memiliki dukungan sosial yang diperoleh dari keluarga.

Ketiga, jumlah anak. Hasil penelitian menunjukkan berapapun jumlah anak yang dimiliki, sama-sama potensial mengalami burnout. Hasil ini sejalan dengan penelitian Suharti \& Daulima (2013). Kondisi keluarga tidak dapat dilepaskan dari burnout pada pekerja, karena salah satu penyebab exhaution, cynicism, dan professional efficacy adalah work - home interference. Anak menjadi salah satu yang mempengaruhi keadaan tersebut. Tidak jarang juga wanita bekerja mengalami konflik peran antara sebagai pekerja dan sebagai ibu. Ibu bekerja sering kali mengalami dilema saat harus membagi waktu antara pekerjaan dan kepentingan keluarga. Terlebih dengan Indonesia yang menganut nilai budaya bahwa tanggung jawab utama wanita adalah mengurus anak dan keluarga. Sedangkan sebagai pekerja profesional wanita juga harus terikat dengan aturan tempatnya bekerja. Kesulitan ini dapat diatasi dengan hadirnya asisten rumah tangga yang mengambil alih tugas ibu dalam mengasuh anak saat ibu sedang bekerja.

Faktor terakhir yang diteliti adalah jabatan struktural. Tidak ada pengaruh jabatan terhadap terjadinya burnout. Hasil ini didukung oleh penelitian Saputri (2017). Jabatan berkaitan dengan otonomi yang dimiliki pekerja. seseorang yang memiliki jabatan cenderung memiliki otonomi yang tinggi. Pemilik jabatan akan lebih leluasa mengatur dirinya dan orang lain. Pada penelitian ini, tidak adanya hubungan kedua variabel tersebut kemungkinan berkaitan dengan tipe kepemimpinan. Pemimpin dalam instansi tempat responden bekerja memberikan otonomi yang cukup pada bawahannya, sehingga memberikan kenyamanan dan kepuasan dalam bekerja (Decy \& Ryan, 2000). 


\section{KESIMPULAN}

Analisis univariat menunjukkan mayoritas responden mengalami burnout ringan sebesar $55 \%$ dan burnout sedang 42,5\%. Analisis bivariat diperoleh hasil terdapat empat faktor yang mempengaruhi burnout pada wanita bekerja di wilayah Kabupaten Banyumas yaitu tingkat pendidikan, jenis pekerjaan/profesi, penghasilan dengan nilai $p 0,000$, dan jam kerja dengan nilai p 0,012. Sedangkan usia, status pernikahan, jumlah anak, dan jabatan struktural tidak mempengaruhi terjadinya burnout karena memiliki nilai $p>0,05$.

\section{SARAN}

Berdasarkan penelitian yang telah dilakukan, terdapat beberapa hal yang dapat disarankan bagi penelitian berikutnya. Sampel penelitian dapat diperluas pada profesi lain. Faktor yang diteliti tidak hanya faktor internal tetapi juga faktor eksternal yang mempengaruhi burnout, seperti dukungan sosial, beban kerja, kondisi lingkungan kerja, dan pemberian reward. Burnout sebaiknya digambarkan lebih detail dari aspek-aspek pendukungnya. Perlu diciptakan lingkungan kerja yang nyaman dengan support system yang adekuat, serta penghargaan yang sesuai untuk menurunkan burnout.

\section{DAFTAR PUSTAKA}

Akhsani, U. (2017). Faktor-faktoryang berhubungan denga burnout pada perawat ICU di RSUD wilayah Kabupaten Banyumas. Skripsi. Purwokerto: Universitas Jenderal Soedirman.

Allarcon, G.M. (2011). A meta analysis of burnoutwith job demand resources and attitude. Journal of Vocational Behavior.79.549562.
Bakker, A.B., Demerouti, E. \& SanzVergel. (2014). Burnout and worker engagement: The DJ-R appoach. Annual Review of Organization Psychology and Organizational Behavior, 1, 389411.

Cooper, C.L. Schabarg, M.J., Winnubst, J.A.M. (2003). The handbook of work and health psychology. $2^{\text {nd }}$ Ed. United State: John Wiley \& Son. Ltd.

Deci, E.C. \& Ryan, R.M. (2000). The what and why of goal pursuit: Human need and the self determination of behavior. Psychologycal Inquiry. 11. 227268.

Departemen Kesehatan Republik Indonesia. (2009). Frofil Kesehatan Indonesia. Jakarta: DepKes RI. Retrieved from http://www.depkes.go.id/resourc es/download/pusdatin/profilkesehatan-indonesia/profilkesehatan-indonesia-2008.pdf

Hakanen, J.J., Bakker, A.B., \& Schaufeli, W.B. (2006). Burnout and work endgagement among teachers. Journal of School Psychology. 43. 495-513.

Keliat, B.A., \& Akemat. (2010). Model Praktik Keperawatan Profesional. Jakarta: EGC.

Maslach, C., \& Later, M. (2008). Early predictors of job burnout and engagement. Journal of Applied Psychology. 93. 498-512.

Mohren, D.C.L. Swaen, G.M.H. Kant, I.J., Van Amelswoort, L.G.P.M. (Borm, P.J.A., \& Galama, J. (2003). Common infections and the role ofburnout in Dutch 
workong population. Journal of Psychosomatic Research. 55. 207-208.

Nelson, K. Boudrias, J.S., Brunet, L. Morin, D. De Civita, M., Savoie, A., \& Aldeson, M. (2014). Authentic leadership and psychological well-being a the individual level of analysis. Burnout Research. 1.90-101.

Nink, M. (2015). The German Work Force Has a Burnout Problem. Bussiness Journal.

Odgen, J. (2004). Health psychology: A textbook. $3^{\text {th }}$ ed. England: Open University Press. Mc Graw-Hill Education.

Peterson, U., Demerouti, E. Bergstrom, G., Samuelsson, M. Asberg, M. Nygren, A. (2008). Burnout and physian and mental health among Swedish health care worker. Journal of Advance Nursing.62. 84-95.

Putnik, K., \& Houkes, I. (2011). Work related characteristics, workhome and homework interference and burnout among primary healthcare physicians: A gender perspective in a Serbian context. BMC Public Health. 11.716 .

Sahin, H. (2012). The levelof burnout of kitchen personel in acommodation facilities. International of Business and Social Science. 3.7.116-120.

Saputri, R.D., Swasti, K.G., Ekowati, W.E. (2017). Gambaran burnout pada dosen FIKes Unsoed. Skripsi. Jurusan Keperawatan FIKes Unsoed.

Spector, P. E. (2008). Industrial and organizational psychology. USA: John Wiley and Sons Inc.

Suharti, N \& Daulima, N.H.C. (2013). Burnout denga kinerja perawat di Rumah Sakit Metropolitan Medical Centre Jakarta. Skripsi. Depok. 